\title{
Pengaruh Zakat Perbankan dan Corporate Social Responsibility terhadap Kinerja PT. Bank Muamalat Indonesia
}

\author{
Nepri Marito', Nofinawati², Ali Hardana ${ }^{3}$ \\ 1,2,3Institut Agama Islam Negeri Padangsidimpuan
}

JL. H.T. Rizal Nurdin Km 4,5 Sihitang Kota Padangsidimpuan, Sumatera Utara marineprito@gmail.com ${ }^{1}$, nofinawati@iain-padangsidimpuan.ac.id ${ }^{2}$, alihardana@iain-padangsidimpuan.ac.id33

\begin{abstract}
The occurrence of an increase or decrease in zakat and CSR followed by Return On Assets (ROA) which is not in accordance with the theory. The purpose of this study was to determine the effect of zakat and CSR on Return On Assets (ROA) at PT. Bank Muamalat Indonesia Tbk. This research is a quantitative research with a descriptive approach. The data source used is secondary data. The analytical tools used are descriptive statistics, normality test, classical assumption test (multicollinearity test, heteroscedasticity, and autocorrelation), multiple linear regression test, partial hypothesis test ( $t$ test) and simultaneously (F test) and the coefficient of determination. The results of the study explain that CSR has an effect on Return On Assets (ROA) and zakat has no effect on Return On Assets (ROA). Simultaneously Zakat and CSR affect the Return On Assets (ROA) at PT. Bank Muamalat Indonesia Tbk and the magnitude of the influence of Zakat and CSR on Return On Assets (ROA) at PT. Bank Muamalat Indonesia Tbk by 30.9 percent.
\end{abstract}

Keywords : Zakat, Corporate Social Responsibility, Return On Assets

\begin{abstract}
ABSTRAK
Terjadinya kenaikan maupun penurunan zakat dan CSR yang diikuti oleh Return On Assets (ROA) yang tidak sesuai dengan teori. Tujuan penelitian ini untuk mengetahui pengaruh zakat dan CSR terhadap Return On Assets (ROA) pada PT. Bank Muamalat Indonesia Tbk. Penelitian ini merupakan penelitian kuantitatif dengan pendekatan deskriptif. Sumber data yang digunakan adalah data sekunder. Alat analisis yang digunakan adalah statistik deskriptif, uji normalitas, uji asumsi klasik (uji multikolinearitas, heteriskedastisitas, dan autokorelasi), uji regresi linear berganda,uji hipotesis secara parsial (uji t) dan serempak (uji F) dan koefisien determinasi. Hasil penelitian menjelaskan bahwa CSR berpengaruh terhadap Return On Assets (ROA) dan zakat tidak berpengaruh terhadap Return On Assets (ROA). Secara simultan Zakat dan CSR berpengaruh terhadap Return On Assets (ROA) pada PT. Bank Muamalat Indonesia Tbk dan besarnya pengaruh Zakat dan CSR terhadap Return On Assets (ROA) pada PT. Bank Muamalat Indonesia Tbk sebesar 30,9 persen.
\end{abstract}

Kata kunci: Zakat, Corporate Social Responsibility, Return On Assets 


\section{PENDAHULUAN}

Kegiatan ekonomi sudah ada sejak Nabi Muhammad SAW, sehingga para ahli ekonomi mulai merancang ekonomi Islam yang sesuai zaman sekarang. Karena itu para ahli ekonomi mulai mengembangkan ekonomi. Bank merupakah ahli dalam sistem keuangan dari suatu negara, dimana tugas utama menghimpun dana dan menyalurkan, sehingga kehadiran dari bank di Indonesia sangat berpengaruh dan memiliki peran yang berarti. Hal ini terjadi karena dengan adanya bank masyarakat merasa nyaman dalam transaksi perbankan. Bank Syariah merupakan bank yang berlandaskan syariah dan sesuai dengan ekonomi Islam. Bank Muamalat Indonesia salah-satunya yang termasuk dalam kategori bank syariah di Indonesia. Dalam penilaian terhadap kinerja Direksi terkait pengelolaan Bank Muamalat Indonesia, Dewan Komisaris menggunakan dua dasar penilaian, yakni pencapaian finansial dan non finansial. Faktor utama yang diukur dari pencapaian finansial ialah pemenuhan target-target yang telah ditetapkan dan disepakati dalam Rencana Bisnis Bank. Di antara indikator tersebut adalah nilai aset, total Dana Pihak Ketiga (DPK), total penyaluran pembiayaan, biaya operasional, pendapatan operasional. Selanjutnya, juga diukur rasio-rasio penting seperti rasio NonPerforming Financing, Return on Asset (ROA), Return on Equity (ROE) serta indikator keuangan lainnya yang lazim digunakan sebagai alat ukur kinerja Bank.

Berdasarkan hasil keterangan dari Dewan Komisaris tersebut Untuk dapat melihat kinerja maupun sistem dari suatu bank syariah salah satunya dapat diukur melalui return on asset (ROA). Return on asset (ROA) adalah rasio pengembalian terhadap total aktiva. Apabila kita berbicara tentang kinerja bank syariah, kita juga akan membahas yang namanya zakat, Karna zakat adalah salah-satu faktor yang menyebabkan kinerja bank syariah meningkat. Dimana Teori konsumsi yang menerangkan bahwa kenaikan jumlah pendapatan akan mempengaruhi pengeluaran seseorang, baik dalam bentuk konsumsi maupun tabungan, termasuk dalam bentuk zakat. Peneliti Zoel Dirga menyimpulkan pendapatan seseorang mendorong secara signifikan keputusan muzakki untuk membayar zakat dan mendorong meningkat besarnya nilai zakat. Pendapatan seseorang akan memberikan pengaruh positif terhadap tingkat pengeluarannya hingga pada batasan tertentu. Zakat juga berpengaruh meningkatkan kinerja bank. Dalam hal ini bank juga mengeluarkan zakat maal yang mencakup hasil perdagangan atau perusahaan. Sesuai dengan firman Allah SWT dalam Q.S At-Taubah (9): 103 yang artinya “Ambillah zakat dari sebagian harta mereka, dengan zakat itu kamu membersihkan dan mensucikan mereka dan berdoalah untuk mereka. 
Sesungguhnya doa kamu itu (menjadi) ketentraman jiwa bagi mereka dan Allah Maha mendengar lagi Maha mengetahui”.

Dari ayat diatas, zakat dapat membersihkan diri dari "cinta harta" yang ditujukan bukan hanya sekolompok tetapi seluruh ummat dan sekaligus dosa amal buruk. Menurut UU No. 17 tahun 2000, tentang penghasilan menyatakan bahwa zakat tidak membebani perusahaan. Namun bank syariah sebagai lembaga bisnis akan memikirkan kondisi kinerja dalam keuangan ketika melakukan kebajikan termasuk zakat. Selain daripada zakat CSR juga merupakan dana dan tanggungjawab sosial yang sama-sama memiliki landasan perundangan. Seperti yang disebutkan diatas CSR berkaitan erat dengan zakat. CSR ialah aktivitas yang seharusnya dilaksanakan semua perusahaan secara sukarela. Tapi banyak perusahaan yang belum melakukannya, sehingga muncul pasal UU No. 40 tahun 2007 tentang Perseroan Terbatas (PT) yang mewajibkan perusahaan melaksanakan CSR. Dengan itu membuat perusahaan lebih dekat dengan masyarakat dan lingkungan sekitar. CSR saat ini ditandai dengan inisiatif standar secara internasional dalam bentuk ISO, ISO 2600o. Dimana menyatakan corporate social resposibility ialah bentuk kepedulian sosial perusahaan saat ini menjadi penting dalam meningkatkan kinerja perusahaan. Bank syariah di Indonesia mendapatkan sumber pendanaannya diantaranya berasal dari dana perusahaan, dana zakat karyawan dan perusahaan, serta dana lainnya seperti sumber lainnya yang halal (infaq dan shadaqoh) dan sumber lainnya yang tidak dapat diakui sebagai pendapatan bank. Berdasarkan PSAK 101 sumber dana kebajikan berasal dari infaq, sedekah, hasil pengelolahan wakaf sesuai dengan perundang-undangan yang berlaku, denda dan pendapatan non halal. Jadi dapat disimpulkan bahwa dana kebajikan suatu perusahaan meruapakan salah satu program corporate social responsibility.

Dalam penelitian ini peneliti menggunakan zakat perbankan dan CSR sebagai variabel yang dapat mempengaruhi daripada kinerja suatu perusahaan karna kinerja keuangan yang baik akan dapat meningkatkan tingkat tanggungjawab perusahaan atau perbankan baik dalam bentuk zakat perusahaan maupun dalam bentuk CSR.

Berikut merupakan zakat perbankan dan Corporate Social Responsibility (CSR) terhadap kinerja perusahaan PT. Bank Muamalat Indoensia Tbk tahun 2012-2020. 
Tabel 1. Nilai zakat, CAR dan ROA pada PT. Bank Muamalat

Indonesia Tbk

\begin{tabular}{|c|c|c|c|}
\hline Tahun & $\begin{array}{c}\text { Zakat } \\
\text { (Jutaan } \\
\text { Rupiah) }\end{array}$ & $\begin{array}{c}\text { CSR } \\
\text { (Jutaan } \\
\text { Rupiah) }\end{array}$ & $\begin{array}{c}\text { ROA } \\
\text { (Persen) }\end{array}$ \\
\hline 2012 & 10.535 & 0 & 1,51 \\
\hline 2013 & 18.509 & 0 & 1,37 \\
\hline 2014 & 22.723 & 3.974 & 0,17 \\
\hline 2015 & 12.533 & 5.690 & 0,20 \\
\hline 2016 & 13.002 & 1.304 & 0,22 \\
\hline 2017 & 15.150 & 882 & 0,11 \\
\hline 2018 & 10.586 & 649 & 0,08 \\
\hline 2019 & 10.869 & 590 & 0,05 \\
\hline 2020 & 10.293 & 361 & 0,03 \\
\hline
\end{tabular}

Sumber: laporan tahunan PT. Bank Muamalat Indonesia Tbk.

Berdasarkan data diatas nilai ROA dari tahun 2012 sampai 2020 mengalami mengalami penurunan kecuali pada tahun 2015 dan 2016 mengalami kenaikan pada tahun sebelumnya, namun jika kita melihat dari nilai zakat dan CSR yang dilakukan oleh Bank Tersebut tahun 2012-2014 mengalami peningkatan. Dan jika kita melihat pada tahun 2015 dan 2016 yang mengalami peningkatan dibidang ROA (0,20 dan 0,22) sangat jauh berbeda jauh dibidang penyaluran dana zakat dan CSR nya (12.553 dan 13.002) mengalami penurunan yang sangat drastis dari tahun sebelumnya yaitu dari tahun 2012 sampai 2014 yang jelas-jelas ROA dari tahun sebelumnnya mengalami peningkatan dari tahun ke tahun baik dari segi kinerja maupun tanggungjawab sosialnya.. Begitu juga pada tahun selanjutnya yaitu pada tahun 2017 yang kinerja menurun, ROA $(0,11)$ yang turun jauh dari tahun 2016 yang ROA nya $(0,22)$ akan tetapi kalau dilihat dari zakat dan CSR nya mengalami peninggkatan yaitu pada tahun 2016 zakat dan CSR nya (13.002 dan 1.304) dan pada tahun 2017 zakat meningkat (15.150) dan CSR nya menurun (882). Begitu juga pada tahun selanjutnya yang kinerjanya menurun dari tahun 2018 sampai 2020 zakat yang dikeluarkan atau penyaluran dananya meningkat antara tahun 2018 (10.586) dan 2019 (10.869) namun pada tahun 2020 (10.293) menurun yang seharusnya dana zakat yang dikeluarkan anatara tahun tersebut menurun akan tetapi mengalami naik turun, akan tetapi jika dilihat dari segi CSR nya 
mengalami penurunan dari tahun 2018 sampai tahun 2020 yang artinya hal tersebut masih sejalan jika kita melihat dari segi ROA nya yang mengalami penurunan dari ketiga tahun tersebut.

Dari data yang telah dipaparkan tersebut seharusnya antara zakat, CSR dan kinerja yang diukur dari ROA mengalami peningkatan dan penurunan yang sejalan karna semakin tinggi kinerja suatu perusahaan tersebut makan tingkat tanggungjawab sosialnya pun semakin tinggi begitu juga sebaliknya. Namun jika dilihat dari data tersebut mengalami kejanggalan yang tidak sesuai antara zakat, ROA dan Kinerjanya.

Hal ini diperkuat oleh penelitian yang dilakukan Ahmad Nurul Muamar dalam penelitiannya yang berjudul analisis kinerja keuangan terhadap kemampuan zakat pada Bank Mandiri dan Bank Mega Syariah. Hasil penelitiannya menunjukkan ada hubungan yang signifikan antara zakat dan kinerja keuangan yang dilihat dari rasio keuangan probabilitas (ROA dan ROE pada bank Syariah). Danu Candra dalam penelitiannya yang berjudul pengaruh corporate social responsibility terhadap kinerja perusahaan. Dengan hasil bahwa CSR berpengaruh positif signifikan terhadap kinerja keuangan perusahaan. Untuk membedakan penelitian terdahulu, penelitian ini menggunakan variabel zakat perbankan dan CSR dengan objek penelitian hanya terfokus pada satu bank syariah saja yaitu PT. Bank Muamalat Indonesia Tbk. Berdasarkan latar belakang permasalahan diatas, maka peneliti tertarik untuk melakukan penelitian dengan judul, "Pengaruh Zakat Perbankan Dan Corporate Social Responsibility Terhadap Kinerja Bank Muamalat Indonesia Tbk Periode 2012-2020 ”.

\section{METODE PENELITIAN}

Penelitian ini dilakukan pada akhir tahun 2020 bulan Oktober sampai selesai September 2021, sedangkan lokasi penelitian yang diteliti PT. Bank Muamalat Indonesia Tbk dengan mengambil data dari situs resmi di www.bankmuamalat.co.id.

Metode penelitian kuantitatif dapat diartikan sebagai metode penelitian yang berlandaskan pada filsafat positivisme, digunakan untuk meneliti pada populasi atau sampel tertentu. Jenis penelitian yang digunakan oleh peneliti termasuk dalam jenis penelitian yang asosiatif yaitu (hubungan) dengan menggunakan metode analisis kuantitatif. 
Populasi dalam penelitian ini ialah laporan triwulan 2012-2020 PT. Bank Muamalat IndonesiaTbk melalui website www.bankmuamalat.co.id. Penelitian ini dalam kurun waktu 2012 sampai 2020 yaitu sebanyak 9 tahun. Dimana dalam setiap satu tahun 4 triwulan sehingga menjadi 36 sampel. Dalam penelitian hanya terdapat satu populasi maka sampel yang diuji pun hanya satu yaitu laporan triwulan tahun 20122020 PT. Bank Muamalat Indonesia Tbk. Teknik pengambilan sampel yang dilakukan dalam penelitian ini adalah sampel jenuh. Sampel jenuh adalah teknik pengambilan sampel bila semua anggota populasi digunakan sebagai sampel.

Jenis data yang digunakan dalam penelitian ini adalah metode dokumenter. Metode ini dilakukan dengan mencatat dan mengumpulkan data-data laporan keuangan PT. Bank Muamalat Indonesia Tbk melalui situs resmi bank tersebut yaitu www.bankmuamalat.co.id.

Variabel yang akan dianalisis pada penelitian ini adalah variabel return on assets (ROA) sebagai variabel dependen dan zakat dan corporate social responsibility sebagai variabel independen. Analisis atau interpretasi dari hasil data penelitian dilakukan dengan menggunakan program SPSS 23. Beberapa metode analisis data yang digunakan dalam penelitian ini, antara lain Uji Statistik Deskriptif, dimana Dalam buku Ghozali, statistik deskriptif memberikan gambaran atau deskriptif suatu data yang dilihat ratarata (mean), standar deviasi, varian, maksimum, minimum dan lain-lain. Analisi ini merupakan teknik deskriptif yang memberikan informasi data yang dimiliki data dan tidak bermaksud untuk menguji hipotesis. Uji Normalitas, jenis uji statistik normalitas, namun yang digunakakan peneliti dalam penelitian ini ialah Kolmogrov-Smirnov. Sampel diambil dari populasi normal, pada a = 0,05. Uji Asumsi Klasik, terdiri dari Uji Multikonearitas, uji Heteroskedastisitas, Uji Autokorelasi dan Uji Regresi Linear Berganda, dimana Dalam regresi berganda terdapat satu variabel terikat lebih dengan satu variabel bebas yang mempengaruhinya.

$\mathrm{Y}=\mathrm{a}+\mathrm{b} 1 \mathrm{X} 1+\mathrm{b} 2 \mathrm{X} 2+\mathrm{e}$

Dari rumus diatas, rumus diatas dapat diturunkan matematika ekonomi sebagai berikut:

$\mathrm{ROA}=\mathrm{a}+\mathrm{b} 1 \mathrm{Z}+\mathrm{b} 2 \mathrm{CSR}+\mathrm{e}$

Keterangan:

ROA = Kesiapan kerja

JISFIM: Journal of Islamic Social Finance Management, Volume 2, No 2 Tahun 2021 http://jurnal.iain-padangsidimpuan.ac.id/index.php/JISFIM 


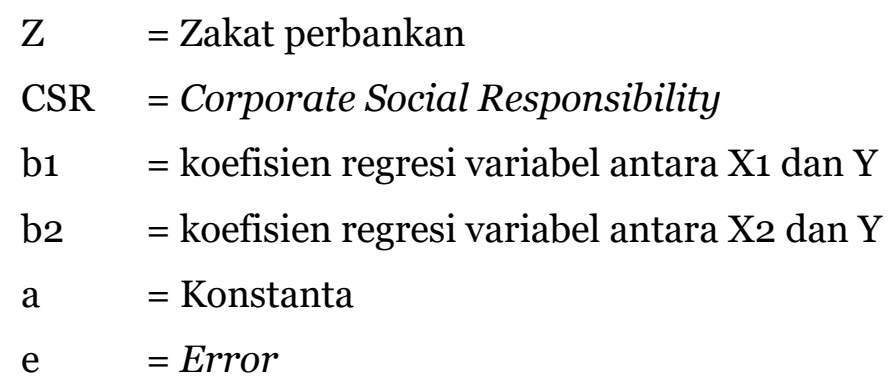

Uji hipotesis, terdiri dari Uji t (uji parsial) dan Uji F (uji serempak). Uji koefisien determinasi $\left(R^{2}\right)$, Dalam penelitian ini menggunakan regresi linier berganda maka masing-masing variabel indenpenden yaitu zakat dan CSR secara parsial dan simultan memengaruhi variabel dependen yaitu kinerja Bank Muamalat Indonesia yang akan dihitung dengan ROA. Dimana $R^{2}$ menyatakan koefisien determinasi serta untuk mengetahui seberapa besar pengaruh zakat dan CSR terhadap kinerja Bank Syariah Indonesia yang dihitung dengan menggunakan ROA.

\section{HASIL DAN PEMBAHASAN}

\section{Kinerja Keuangan Bank}

Untuk menilai apakah tujuan yang telah ditetapkan sudah dicapai bukanlah sesuatu yang mudah dilakukan. Kinerja perusahaan secara umum biasanya akan direpresentasikan dalam laporan keuangan. Dalam menganalisis kinerja keuangan perusahaan, maka diperlukan beberapa jenis rasio, yaitu Rasio Likuiditas, Rasio Solvabilitas dan Rasio Profitabilitas

Dan dalam penelitian ini peneliti menggunakan rasio profitabilitas sebagai tolak ukur kinerja dari suatu bank atau perusahaan dalam proses kinerjanya dimana peneloti menggunakan ROA sebagai salah satu bahagian dari profitabilitas. Penelitian ini menggunakan Analisis Return On Asset (ROA), karena Return on Asset (ROA) digunakan untuk mengukur kemampuan manajemen bank dalam memperoleh keuntungan yang dihasilkan dari rata-rata total aset bank yang bersangkutan. ROA merupakan perbandingan antara laba sebelum pajak dengan total aset dalam suatu periode, rumus yang digunakan untuk mencari ROA adalah sebagai berikut:

ROA: Laba bersih $\times 100 \%$

Total aktiva 


\section{Zakat perbankan}

Zakat ratio (ZR) perbankan syariah di Indonesia menggunakan komponen berbasis pada aset bersih dengan laba sebelum pajak. Semakin tinggi komponen ini, mengindikasikan zakat ratio (ZR) perbankan syariah baik, sebaliknya semakin rendah komponen ini mengindikasikan zakah ratio (ZR) perbankan syariah yang tidak baik.

\section{Corporate Social Responsibility}

Pelaksanaan program CSR dalam Islam menggunakan pendekatan konsep maslahah dan maqasid syariah dalam penentuan kebijakan pelaksanaan CSR. Hal ini dapat membantu pengelola bank syariah untuk menyelesaikan pilihan-pilihan rumit dalam pelaksanaan CSR, sehingga CSR bank syariah benar-benar dilaksanakan bukan hanya untuk memenuhi kewajiban, baik kewajiban syariah maupun kewajiban Undangundang, akan tetapi lebih jauh dari itu CSR bank syariah dapat menyelesaikan dan meringankan problematika sosial dalam masyarakat terutama memberdayakan ekonomi masyarakat lemah.

Bank Muamalat Indonesia merupakan bank syariah pertama di Indonesia yang berdiri pada 1 November 1991 atau 24 Rabiul Akhir 1412 H. Mulai beroperasi pada 1 Mei 1992 atau 27 Syawal $1412 \mathrm{H}$ dan menjadi pelopor bisnis keuangan syariah lainnya. Visi Bank Muamalat Indonesia Tbk Yaitu Menjadi Bank Syariah Terbaik dan termasuk dalam 10 Bank Terbesar di Indonesia dengan eksistensi penguasaan yang diakui di tingkat regional. Sedangkan Yaitu Membangun Lembaga Keuangan Syariah yang Unggul dan Berkesinambungan dengan penekanan pada semangat kewirausahaan berdasarkan prinsip kehati-hatian, keunggulan sumber daya manusia yang islami dan profesional serta orientasi investasi yang inovatif untuk memaksimalkan nilai kepada seluruh pemangku kepentingan.

JISFIM: Journal of Islamic Social Finance Management, Volume 2, No 2 Tahun 2021 http://jurnal.iain-padangsidimpuan.ac.id/index.php/JISFIM 


\section{Statistik Deskriptif}

Berikut hasil analisis statistik deskriptif pada PT. Bank Muamalat Indonesia Tbk.

Tabel 2. Hasil Uji Statistik Deskriptif

\begin{tabular}{|c|c|c|c|c|c|c|}
\hline \multirow{2}{*}{ Variabel } & \multirow{2}{*}{$\mathbf{N}$} & \multirow{2}{*}{ Minimum } & \multirow{2}{*}{ Maximum } & \multicolumn{2}{|c|}{ Mean } & \multirow{2}{*}{$\begin{array}{c}\text { Std. } \\
\text { Deviation }\end{array}$} \\
\hline & & & & Statistic & $\begin{array}{c}\text { Std. } \\
\text { Error }\end{array}$ & \\
\hline ZAKAT & 36 & 2 & 856 & 32,20 & 23,554 & 141,322 \\
\hline CSR & 36 & o & 882 & 253,06 & 46,746 & 280,476 \\
\hline ROA & 36 & 2,00 & 172,00 & 55,5000 & 10,60028 & 63,60166 \\
\hline $\begin{array}{l}\text { Valid N } \\
\text { (listwise) }\end{array}$ & 36 & & & & & \\
\hline
\end{tabular}

Sumber: hasil output SPSS versi 23, data diolah

Berdasarkan tabel 2 dapat disimpulkan bahwa statistik deskriptif pada perusahaan PT. Bank Muamalat indonesia Tbk dengan jumlah sampel 36 yang diambil dari laporan triwulan selama 9 tahun. Berdasarkan hasil tersebut nilai zakat minimum sebesar 2 dan maksimum 856 dengan rata-rata sebesar 32.20 dengan standar eror 23.554 kemudian nilai deviasi sejumlah 141.322. Corporate social responsibility (CSR) diperoleh nilai minimum o dan maksimum 882 dengan nilai rata-rata 253.06 dan memiliki standar eror 46.746 serta memiliki nilai standar deviasi sebesar 280.476 hal ini menunjukkan kesadaran Bank Muamalat Indonesia untuk melakukan zakat perusahaannya. Return on assets (ROA) diperoleh nilai minimum sebesar 2.00 dan maksimum 172.00 dengan rata-rata sebesar 55.5000 memiliki standar eror sebesarr 10.60028 dan standar deviasi sebanyak 63.60166 .

\section{Uji Normalitas}

Uji normalitas data digunakan untuk mengecek apakah data yang diteliti tersebut berasal dari populasi yang mempunyai sebaran normal atau tidak. Untuk menguji normalitas data dapat menggunakan pendekatan kolmogrov-smirnov. 
Tabel 3. Hasil uji Normalitas One-Sample Kolmogorov-Smirnov Test

\begin{tabular}{|c|c|c|}
\hline \multicolumn{2}{|l|}{ Keterangan } & Nilai \\
\hline \multirow[t]{3}{*}{ Normal Parameters ${ }^{\mathrm{a}, \mathrm{b}}$} & Mean & 0,0000000 \\
\hline & Std. & 52,87417931 \\
\hline & Deviation & \\
\hline Extrem & Extreme Absolute & 0,105 \\
\hline \multirow[t]{2}{*}{ Differences } & Positive & 0,105 \\
\hline & Negative & $-0,098$ \\
\hline \multicolumn{2}{|l|}{ Test Statistic } & 0,105 \\
\hline \multicolumn{2}{|l|}{ Asymp. Sig. (2-tailed) } & $0,200^{c, d}$ \\
\hline
\end{tabular}

Sumber: hasil output SPSS versi 23, data diolah

Berdasarkan Tabel 3 diketahui bahwa nilai Unstandardized residual sig $=0,200$ > 0,05 sehingga dapat disimpulkan bahwa data yang diuji berdistribusi normal.

\section{Uji Asumsi Klasik}

\section{Uji Multikolinearitas}

Untuk mengetahui ada tidaknya masalah multikolinieritas dapat menggunakan nilai VIF (Variance Inflation Factory). Jika nilai VIF masih kurang dari 10, multikolinieritas tidak terjadi.

Tabel 4. Hasil Uji Multikolinearitas

\begin{tabular}{lcc}
\hline \multirow{2}{*}{ Model } & \multicolumn{2}{c}{ Collinearity Statistics } \\
\cline { 2 - 3 } & Tolerance & VIF \\
\hline (Constant) & 0,975 & 1,026 \\
ZAKAT & 0,975 & 1,026 \\
CSR & & \\
\hline
\end{tabular}

Berdasarkan tabel 4 menunjukkan bahwa Variance Inflation Factor (VIF) untuk penyaluran dana zakat yaitu 1,026 dan Corporate Social Responsibility (CSR) sebesar 1,026. Dengan demikian, nilai kedua variabel tersebut kurang dari 10 maka variabel 
tersebut bebas dari masalah multikolinieritas dikarenakan Variance Inflation Factor (VIF) pada variabel tersebut kurang dari 10. Dengan demikian data penelitian ini layak untuk dipakai.

\section{Uji Heteroskedastisitas}

Uji heteroskedastisitas merupakan uji untuk mengetahui apakah dalam sebuah model regresi dalam penelitian, terjadi ketidaksamaan varian dan residual yang diamati. Apabila varian yang diamati bersifat tetap, keadaan disebut sebagai homoskedastivitas. Sebaliknya jika varian yang diamati berubah disebut heteroskedastivitas.

Jika nilai signifikan ( $p$-value) semua variabel independen > 0,05 maka varian residual homogen (tidak terjadikasus heteroskedastisitas).

Tabel 5. Hasil uji Heteroskedastisitas Coefficientsa

\begin{tabular}{lccccc}
\hline \multirow{2}{*}{ Model } & \multicolumn{2}{c}{$\begin{array}{c}\text { Unstandardized } \\
\text { Coefficients }\end{array}$} & $\begin{array}{c}\text { Standardized } \\
\text { Coefficients }\end{array}$ & T & \multirow{2}{*}{ Sig. } \\
\cline { 2 - 4 } & $\mathbf{B}$ & Std. Error & Beta & & \\
\hline (Constant) & 0,614 & 0,263 & & 2,333 & 0,029 \\
X1_2 & 0,020 & 0,124 & 0,034 &, 161 & 0,874 \\
X2_2 & $-1,125 \mathrm{E}-6$ & 0,000 & $-0,280$ & $-1,332$ & 0,197 \\
\hline
\end{tabular}

a. Dependent Variable: ABS_2

Sumber: hasil output SPSS versi 23, data diolah

Berdasarkan hasil perhitungan dari output uji glejser pada tabel 5 di atas menunjukkan tidak ada gangguan heteroskedastisitas yang terjadi dalam proses estimasi parameter model praduga, dimana nilai signifikansi variabel zakat sebesar o,874 lebih besar dari 0,05 dan nilai CSR sebesar 0,197 lebih besar dari 0,05. Jadi dapat disimpulkan bahwa tidak ada masalah heteroskedastisitas.

\section{Uji Autokorelasi}

Uji Autokorelasi bertujuan untuk mengetahui apakah dalam model regresi ada regresi antar kesalahan pengganggu pada periode $(\mathrm{t}$ ) dengan periode $\mathrm{t}-1$ (sebelumnya). Pengujian autokrelasi menggunakan Durbin Watson. Jika angka D-W diantara -2 sampai +2, berarti tidak terjadi autokorelasi. Hasil uji autokorelasi sebagai berikut: 
Tabel 6. Hasil uji Autokorelasi Model Summaryb

\begin{tabular}{cc}
\hline Model & Durbin-Watson \\
\hline 1 & 1,500 \\
\hline
\end{tabular}

Sumber: hasil output SPSS versi 23, data diolah

Dari tabel 6 diatas menunjukkan bahwa nilai Durbin Watson berada diangka 2, maka dapat dikatakan tidak terjadi autokorelasi.

\section{Uji Regresi Linear Berganda}

Penelitian ini menggunakan pengujian hipotesis analisis regresi linear berganda. Uji Regresi ini digunakan untuk melihat adanya pengaruh Variabel dependen penelitian ini yaitu pertumbuhan kinerja/ROA (Y) sedangkan variabel independen dalam penelitian ini adalah zakat perbankan dan Corporate Social Responsibility (CSR). berikut adalah tabel 7 hasil dari pengujian hipotesis.

Tabel 7. Hasil Uji Linier Regresi Berganda Coefficients ${ }^{a}$

\begin{tabular}{lccccc}
\hline \multirow{2}{*}{ Model } & \multicolumn{2}{c}{$\begin{array}{c}\text { Unstandardized } \\
\text { Coefficients }\end{array}$} & $\begin{array}{c}\text { Standardized } \\
\text { Coefficients }\end{array}$ & t & Sig. \\
\cline { 2 - 4 } & B & Std. Error & Beta & & \\
\hline (Constant) & 81,397 & 12,777 & & 6,370 & 0,000 \\
ZAKAT & 0,082 & 0,066 & 0,182 & 1,241 & 0,223 \\
CSR & $-0,113$ & 0,033 & $-0,497$ & $-3,393$ & 0,002 \\
\hline
\end{tabular}

a. Dependent Variable: ROA

Sumber: hasil output SPSS versi 23, data diolah

Hasil uji regresi linier sederhana pada tabel di atas menunjukkan persamaan regresi dengan pengungkapan zakat dan CSR (independen) dan ROA (dependen). Koefisien regresi zakat sebesar 0,082 bertanda positif dan koefisien regresi CSR 0,113 bertanda negative artinya menunjukkan setiap kenaikan $1 \%$ tingkat pelaporan zakat makan ROA mengalami kenaikan sebesar 0,082 atau 82\%. Koefisien regresi bernilai positif berarti terjadi hubungan positif antara zakat dan ROA. Sedangkan setiap kenaikan 1\% tingkat pelaporan CSR maka ROA mengalami kenaikan sebesar 0,113 atau $11,3 \%$. Koefisien regresi bernilai negatif berarti terjadi hubungan negatif antara 
pelaporan CSR dan ROA, yakni semakin besar pengungkapan CSR yang dilakukan maka akan menurunkan ROA. Adapun persamaan regresi berdasarkan tabel di atas adalah:

$\mathrm{ROA}=\mathrm{a}+\mathrm{b} 1 \mathrm{Z}+\mathrm{b} 2 \mathrm{CSR}+\mathrm{e}$

$\mathrm{ROA}=81.397+0.407 \mathrm{Z}-0.113 \mathrm{CSR}+12.777$

\section{Hasil Uji Hipotesis}

\section{Uji Parsial (Uji t)}

Tabel 8. Hasil Uji t Coefficients ${ }^{a}$

\begin{tabular}{ccc}
\hline \multirow{2}{*}{ Model } & T & Sig. \\
\cline { 2 - 3 } & $\mathbf{B}$ & \\
\hline (Constant) & 6,370 & 0,000 \\
ZAKAT & 1,241 & 0,223 \\
CSR & $-3,393$ & 0,002 \\
\hline
\end{tabular}

Pengujian variabel zakat terhadap ROA menghasilkan nilai $t_{\text {hitung }}<t_{\text {tabel }}$ sebesar $1.241<2.035$ dan nilai sig diperoleh signifikansi uji t sebesar 0,223 lebih besar dari 0,05 maka $\mathrm{H}_{1}$ ditolak artinya tidak ada pengaruh antara variabel zakat terhadap ROA.

Pengujian CSR terhadap ROA menghasilkan nilai $-\mathrm{t}_{\text {hitung }}<-\mathrm{t}_{\text {tabel }}$ sebesar -3.393 $<-2,035$ dan diperoleh signifikansi uji t sebesar 0,002 lebih kecil dari 0,05 maka $\mathrm{H}_{2}$ diterima sehingga terdapat pengaruh antara CSR terhadap ROA secara signifikan. Artinya secara parsial ada pengaruh signifikan antara Corporate Social Responsibility (CSR) dengan Return On Assets (ROA). Jadi dari penelitian ini dapat disimpulkan bahwa secara parsial CSR berpengaruh terhadap ROA pada PT. Bank Muamalat Indonesia Tbk.

\section{Uji Simultan (Uji F)}

Uji $\mathrm{F}$ adalah pengujian signifikansi persamaan yang digunakan untuk mengetahui seberapa besar pengaruh variabel independen (X1 dan X2) secara bersamasama terhadap variabel dependen (Y). 
Tabel 9. Hasil Uji F ANOVAa

\begin{tabular}{lccccc}
\hline \multicolumn{1}{c}{ Model } & Sum of Squares & Df & Mean Square & F & Sig. \\
\hline Regression & 43732,241 & 2 & 21866,120 & 7,374 & O,OO2 $^{\text {b }}$ \\
Residual & 97848,759 & 33 & 2965,114 & & \\
Total & 141581, ooo & 35 & & & \\
\hline
\end{tabular}

a. Dependent Variable: ROA

b. Predictors: (Constant), CSR, ZAKAT

Sumber: hasil output SPSS versi 23, data diolah

Dari tabel 9 diperoleh $F_{\text {hitung }}$ sebesar 7,374 dan nilai probabilitas (sig.) sebesar 0,002. Nilai $F_{\text {hitung }}(7,374)>F_{\text {tabel }}(3,28)$ maka model regresi yang dihasilkan sesuai.

\section{Hasil Koefisien Determinasi}

Untuk mengetahui besar pengaruh dari X1, dan X2, terhadap Y dapat diketahui dengan menghitung nilai $R$ square (koefisien determinasi. Nilai $R$ square hasil pengujian regresi dapat dilihat pada Tabel 4.12

Tabel 1o. Hasil Uji Koefisien Determinasi Model Summary

\begin{tabular}{ccccc}
\hline Model & $\mathrm{R}$ & R Square & $\begin{array}{c}\text { Adjusted R } \\
\text { Square }\end{array}$ & $\begin{array}{c}\text { Std. Error of } \\
\text { the Estimate }\end{array}$ \\
\hline & $0,556^{\mathrm{a}}$ & 0,309 & 0,267 & 54,45286 \\
\hline
\end{tabular}

\section{a.Predictors: (Constant), CSR, ZAKAT}

Berdasarkan hasil yang ditunjukkan pada tabel 10 menunjukan koefisien korelasi (R) sebesar 0,556 ini berarti ada hubungan antara variabel ROA dengan variabel Zakat dan CSR,. Nilai R Square yang diperoleh sebesar 0,309 menunjukkan bahwa pengaruh $\mathrm{X}_{1}$, dan $\mathrm{X}_{2}$ terhadap $\mathrm{Y}$ adalah sebesar 0,309 yaitu 30,9 persen dan sisanya 69,1 persen dipengaruhi oleh faktor lain selain zakat, dan CSR yang tidak masuk dalam model pembahasan. 


\section{KESIMPULAN}

Berdasarkan hasil pengelolaan data dari penelitian yang berjudul "Pengaruh Zakat Perbankan dan Corporate Social Responsibility kinerja PT.Bank Muamalat Indonesia Tbk periode 2012-2020" didapatkan kesimpulan sebagai berikut secara parsial, variabel Zakat Perbankan menghasilkan nilai $t_{\text {hitung }}<t_{\text {tabel }}$ sebesar $1.241<2.035$ dan memiliki nilai sig > 0,05 maka dapat disimpulkan H1 ditolak. dari uji tersebut dapat disimpulkan bahwa variabel Zakat Perbankan secara parsial tidak berpengaruh signifikan terhadap Return On Asset PT. Bank Muamalat Indonesia Tbk tahun 20122020. Secara parsial, variabel Corporate Social Responsibility menghasilkan nilai $\mathrm{t}_{\text {hitung }}<-\mathrm{t}_{\text {tabel }}$ sebesar -3.393 < -2.035 dan memiliki nilai sig < 0,05 maka dapat disimpulkan H2 diterima . Jadi dari uji tersebut d apat disimpulkan bahwa variabel Corporate Social Responsibility secara parsial berpengaruh signifikan terhadap return on asset PT. Bank Muamalat Indonesia Tbk tahun 2012-2020. Secara simultan, variabel Zakat Perbankan dan Corporate Social Responsibility menghasilkan Fhitung sebesar 7,374 . Nilai $F_{\text {hitung }}(7,374)>F_{\text {tabel }}(3,28)$ dan memiliki nilai sig 0,002 yang berarti bahwa kedua variabel tersebut secara simultan mempengaruhi variabel Return On Asset PT. Bank Muamalat Indonesia Tbk tahun 2012-2020. 


\section{DAFTAR PUSTAKA}

Ali, Muhammad. Statistik Penelitian Bidang Pendidikan, Psikologi Dan Sosial. Yogyakarta: Parama Publishing, April 2015. Hlm. 46.

Harlan Johan. Analisi Regresi Linier. Depok: Gunadarma, 2018.

Muh. Taslim Dangnga dan M. Ikhwan Maulana Haeruddin. Kinerja Keuangan Perbankan: Upaya Untuk Menciptakan Sistem Perbankan Yang Sehat. CV. Nur Lina, 2018.

Nizar Rangkuti, Ahmad. Metode Penelitan Pendidikan. Medan: Citapustaka Media, 2016.

Rachman, Nurdizal M., Asep Efeandi dan Emir Wicaksan. Panduan Lengkap Perencanaan CSR, Jakarta: Penebar Swadaya. 2011.

Siyoto, Sandu dan M. Ali Sodik. Dasar Metodologi Penelitian. Yogyakarta: Literasi Media Publishing, 2015.

Syahrum dan Salim. Metodologi Penelitian Kuantitatif. Bandung: Citapustaka media, 2012.

Tri Cahyono. Statistic Uji Normalitas, Purwokerto: Yayasan Sanitarian Banyumas Yasamas, 2015 .

Zainal A. Metodologi Penelitian Pada Bidang Ilmu Komputer Dan Teknologi Informasi”. Depok: Fasilkom Universitas Indonesia, 2007.

Adi Putro, R. Yudha, Mustapha Kamal. "Analisis Pengaruh Brand Reputation, Brand Competence, Dan Brand Liking Terhadap Trust In Brand Pada Konsumen Windows Phone Nokia Di Surabaya”. Jurnal Studi Manajemen \& Organisasi, Vol. 10, No. 2, Juli, Thn 2013.

JISFIM: Journal of Islamic Social Finance Management, Volume 2, No 2 Tahun 2021 http://jurnal.iain-padangsidimpuan.ac.id/index.php/JISFIM 
Ade Rosita, Ni Wayan, Isharijadi Dan Juli Murwani. "Pengaruh Ukuran Perusahaan Dan Profitabilitas Terhadap Harga Saham Pada Perusahaan Jasa Yang Terdaftar di BEI". The 11th FIPA Forum Ilmiah Pendidikan Akuntansi Progam Studi Pendidikan Akuntansi-Fkip Universitas Pgri Madiun.

Astuti, Andjar dan Windu Mulyasari. "Pelaksanaan Corporate Social Responsibility (CSR) dan Efektivitas Kemanfaatannya Untuk Masyarakat Sekitar Industry Di Kokta Cilegon”. jurnal Tirtayasa Ekonomika, Vol. 11, Nop. 2, Oktober 2016.

Dahlan, Dahlia. "Bank Zakat: Pengelolahan dengan Konsep Bank Sosial Berdasarkan Prinsip Syariah”. Jurnal Ekonomi dan Bisnis Islam, Vol. 4, No. 2, Desember 2018.

Febby Rhamadhani, Rika. "Pengaruh Zakat Terhadap Kinerja Perusahaan (Studi Empiris pada Bank Umum Syariah di Indonesia)”. Jurnal Studia Islamika, Vol. 13, No. 2 Desember 2016.

Firdaningsih, Muhammad Sri Wahyudi dan Rahmad Hakim. "Delapan Golongan Penerima Zakat Analisis Teks Dan Konteks”. jurnal ekonomi syariah, Vol. 7, No. $2,2019$.

Hadi, A.Khairul. "Corporate Social Responsibility Dan Zakat Perusahaan Dalam Perspektif Hukum Ekonomi Islam”. Ahkam, Vol. XVI, No. 2, Juli 2016.

Hariyanto, Erie dan Moh. Ali Al-Humaidy. "Pelaksanaan Corporate Social Responsibility dan Zakat Perusahaan Perbankan Syari'ah di Madura”. Jurnal Hukum \& Pembangunan 49 No. 32019.

Imam Purwadi, Muhammad. "Al-Qardh dan Al-Qardhul Hasan sebagai Wujud Pelaksanaan Tanggung Jawab Sosial Perbankan Syariah”. Jurnal Hukum IUS QUIA IUSTUM NO. 1 Vol. 21 Januari 2014. 
Indah, Ririn Nur dan Hady Siti Hadijah, "Peningkatan Kinerja Pegawai Melalui Kepuasan Kerja dan Disiplin Kerja”, Jurnal Pendidikan Manajemen Perkantoran, Vol. 1 No. 1, Agustus 2016.

Maguni, Wahyudi dan Haris Maupa. "Teori Motivasi, Kinerja, dan Prestasi Kerja Dalam Al-Qur'an Serta Flektibilitas Penerapannya Pada Manajemen Perbankan Islam”. Jurnal Studi Ekonomi dan Bisnis Islam Vol. 3, No. 1 Juni 2018.

Marimin, Agus., Abdul Haris Romdhoni dan Tira nur Fitria. "perkembangan bank syariah di Indonesia”. Jurnal Ilmiah Ekonomi Islam vol. 01 No. 02, juli 2015.

Muslihati, Siradjuddin dan Syahruddin. "Corporate Social Responsibility (CSR) Dalam Perspektif Ekonomi Islam Pada Bank Syariah”. Jurnal Hukum Ekonomi Syariah, Vol. 2, No. 1, Januari-Juni 2018.

Nofinawati. "Penerapan Fungsi Sosial Bank Syariah Dan Dampaknya Terhadap Kesejahteraan Masyarakat Padangsidimpuan”. Jurnal Al Qardh, No. 5, Desember 2018

Oktarina, Aminah. "Program Corporate Social Responsibility perbankan Syariah di Bidang Pengelolahan Ikan Sebagai Alternatife Pemberdayaan UMKM Jangka Panjang”. Al-Intaj, Vol. 2, No. 2, September 2016.

Pipi Sumanni Manullang, Nofinawati, Jumi Atika, "Pengaruh Zakat terhadap Rasio Net Profit Margin (NPM) pada PT. Bank Syariah Mandiri Tbk”, Journal of Islamic Social Finance Management Vol. 1,No. 1

Rahmadhani, Rika Febby. "Penagruh Zakat Terhadap Kinerja Perusahaan(Study Empirism Pada Bank Umum Syariah di Indonesia). Jurnal StudiaIslamika Vol. 13, No. 2 Desember 2016.

Riwayati, Sri dan Nurul Bidayatul Hidayah, "Zakat Dalam Telaah QS. AT-TAUBAH: 103 (Penafsiran Enam Kitab), Jurnal Ilmu Dan Tafsir, Vol. 1, No. 2, Desember 2018. 
Shalihah, Maratun dan Mahwa Soraya Tuasikal, "Efektivitas Program CSR Pada Bank Syariah Mandiri di Kota Ambon”. Tahkim, Vol. XVI, No. 1, Juni 2018.

Suprihati. "Analisis Faktor-Faktor Yang Mempengaruhi Kinerja Karyawan Perusahaan Sari Jati di Sragen”. Jurnal Paradigma, Vol. 12, No. 01, Februari-Jul;I 2014.

Wahyudi, Rofiul "Pengaruh Kinerja Keuangan Terhadap Zakat Perbankan Syariah Di Indonesia”. Jurnal Muqaddimah Vol. 21 No. 2 Tahun 2015.

Wahyuningsih, Panca dan Maduretno Widowati. “Analisis Roa Dan Roe Terhadap Nilai Perusahaan Dengan Corporate Social Responsibility Sebagai Variabel Moderating (Studi Pada Perusahaan Bumn Yang Terdaftar Di Bei Periode 20102013)”. Jurnal Stie Semarang Vol. 8 No. 3.

Yusuf, Ali dan Qomaruddin. "Mekanisme Pengelolahan Dana Zakat, Infaq, dan Shadaqahdi Bank Syariah Sebagai Implementasi Fungsi Sosial Bank(Studi Kasus di BPR Syariah Amanah Ummah)”. Jurnal Syarikah Vol. 1, No. 1, Juni 2015.

Yohani dan Yususf. "Pengaruh Zakat, Infaq Dan Shodaqoh Terhadap Laba Pada Perbankan Syariah Di Indonesia”. majalah neraca, 2014.

Chandra Indrawan, Danu Chandra. "Corporate Social Responsibility Terhadap Kinerja Perusahaan”. Skripsi (UNDIP Semarang, 2011).

Finandra Hana, Zerra Restavia. “ Berjudul Pengaruh Pengungkapan Corporate Social Responsibility Terhadap Kinerja Keuangan Perusahaan Telekomunikasi Yang Terdapat Di Bursa Efek Indonesia”. Skripsi (Universitas Brawijaya).

Muammar, Ahmad Nurul. "Analisis Kinerja Keuangan Terhadap Kemampuan Zakat Pada Bank Mandiri Dan Bank Mega Syariah.”. Skripsi (Institut Agama Islam Negeri Walisongo), 2010.

Romadhan Rokhmat. "Evaluasi Kritis Ketepatan Dana Kebajikan Dan Zakat Sebagai Sumber Dana Pertanggungjawaban Sosial (Studi Kasus Pada Bank Syariah http://jurnal.iain-padangsidimpuan.ac.id/index.php/JISFIM 
209 I Pengaruh Zakat Perbankan dan Corporate Social Responsibility terhadap Kinerja PT. Bank Mu a malat Indonesia

Mandiri, Bank Muamalat Indonesia, dan Bank Negara Indonesia Syariah Tahun 2015). Skripsi (Universitas Muhammadiyah Yogyakarta, 2017).

UU No. 40 Tahun 2007 Tentang Perseroan Terbatas. 